\title{
Diagnostic Utility of Measuring First Day Serum Bilirubin Levels in Management of Neonatal Hyperbilurubinemia
}

\author{
R Rama Krishna Paramahamsa ${ }^{1}$, Gangina Sriram², Swetha Koneru³, T Jaya Chandra ${ }^{4}$ \\ ${ }^{1}$ Associate Professor, department of Pediatrics, GSL Medical College, Rajahmundry, ${ }^{2}$ Associate Professor, department of Pediatrics, GSL Medical College, Rajahmundry, \\ ${ }^{3}$ Resident, department of Pediatrics, GSL Medical College, Rajahmundry, ${ }^{4}$ Scientist inchrage, Central Research laboratory, GSL Medical College, Rajahmundry.
}

\section{Abstract}

Background: Hyperbilirubinemia is the commonest finding in the first week of life, cause of concern for the parents and pediatricians. Objectives: With this study was carried to evaluate the predictive value of serum bilirubin level on day one postnatal age for identifying term neonates at risk for subsequent hyperbilirubinemia. Subjects and Methods: Study was conducted in GSL Medical College. Study protocol was approved by institutional ethics committee. Informed consent was collected from the parents / guardians of all the study participants. Neonates $\geq 37$ weeks who were otherwise healthy were included in the study. First serum bilirubin measurement was estimated initially within $24 \pm 2$ hours of life. Second serum bilirubin estimation estimation was attempted if clinical assessment of serum bilirubin $>10 \mathrm{mg} / \mathrm{dl}$. Results: Total 200 healthy term newborns were evaluated; male female ratio was 1.2. The mean gestation period was 39.24 \pm 1.12 weeks. Maximum (58\%; 116) women had full term normal vaginal delivery. The range of bilirubin on day one was $2.2-8.5 \mathrm{mg} / \mathrm{dl}$; majority newborns ( $86.5 \%$ ) did not develop significant hyperbilirubinemia. Conclusion: Early screening and appropriate management of hyperbilirubinemia is needed for prevention of complications in the newborn. This decreases the significant burden of untreated severe neonatal jaundice, causing potential neurological sequelae.

Keywords: Serum, Bilurubin.

Corresponding Author: Dr Gangina Sriram, Associate Professor, Department of Pediatrics, GSL Medical College, Rajahmundry.

Received: November 2019

Accepted: November 2019

\section{Introduction}

Hyperbilirubinemia is the commonest finding in the first week of life, cause of concern for the parents and pediatricians. To the pediatrician jaundice remains the most common problem in the well-baby nursery. Jaundice is observed during the first week of life in approximately $60 \%$ of term infants and $80 \%$ of preterm infants. ${ }^{[1]}$

Bilirubin production is 2-3 times higher in normal term newborns compared with adults. Unconjugated (indirect) hyperbilirubinemia occurs as a result of excessive bilirubin formation and because the neonatal liver cannot clear bilirubin rapidly enough from the blood. ${ }^{[2,3]}$

Under normal circumstances, the level of indirect reacting bilirubin in umbilical cord serum is $1-3 \mathrm{mg} / \mathrm{dl}$ and rises at a rate of less than $5 \mathrm{mg} / \mathrm{dl} / 24 \mathrm{hrs}$. Immature new born brain is susceptible to toxicity from unconjugated bilirubin, resulting in neuro developmental or intellectual handicaps and finally frank kernicterus. Hence early detection and appropriate management of neonatal jaundice is of paramount importance in preventing kernicterus.

Although most newborns with jaundice are otherwise healthy, every baby who is jaundiced necessitates attention at the earliest to look for features of pathological jaundice because unconjugated bilirubin is potentially toxic to the central nervous system. ${ }^{[4]}$ Routine obstetric and neonatal hospital stays have decreased markedly in world during past 15 - 20 years. Early discharge of healthy term newborns after delivery has become a common practice because of medical and social reasons and economic constraints.

Several studies suggest that neonatal hyperbilirubinemia is the most common cause for readmission of healthy term babies discharged early. ${ }^{[2,5,6]}$ In up to $4 \%$ of term newborns who are readmitted to the hospital during their first week of life, approximately $85 \%$ are readmitted for jaundice. ${ }^{[7]}$ There have been reports of a correlation between bilirubin values on day one of life and subsequent hyperbilirubinemia [8, 9] Infants with high serum bilirubin levels will have high peak subsequently. Infants who are clinically jaundiced in the first few days are more likely to develop hyperbilirubinemia. ${ }^{[2,10]}$

With this study was carried to evaluate the predictive value of serum bilirubin level on day one postnatal age for identifying term neonates at risk for subsequent hyperbilirubinemia.

\section{Subjects and Methods}

Study was conducted in GSL Medical College. Study 
protocol was approved by institutional ethics committee. Informed consent was collected from the parents / guardians of all the study participants. Neonates $\geq 37$ weeks who were otherwise healthy were included in the study. Preterm babies <37weeks gestational age, neonates with significant illness requiring NICU admission $>12$ hours, Rhincompatibility, evidence of hemolysis, with major congenital malformations, with conjugated hyperbilirubinemia who were born with birth asphyxia, septicemia were not considered; Neonates who developed direct hyperbilirubinemia, features suggestive of sepsis, respiratory distress were excluded from the study

First serum bilirubin measurement was estimated initially within $24 \pm 2$ hours of life. The babies were then followed up clinically using Kramer's rule for appearance and progression of jaundice every 12 hours up to 5 days of life. Second serum bilirubin estimation estimation was attempted if clinical assessment of serum bilirubin $>10 \mathrm{mg} / \mathrm{dl}$ i.e. presence of jaundice below the level of umbilicus. Primary outcome was defined as presence of hyperbilirubinemia when serum bilirubinlevel $\geq 12 \mathrm{mg} / \mathrm{dl}$ at 25 to $48 \mathrm{hr}$ of life, $\geq 15 \mathrm{mg} / \mathrm{dl}$ between 49 to $72 \mathrm{hr}$ and $\geq 17 \mathrm{mg} / \mathrm{dl}$ beyond $72 \mathrm{hr}$ of life. Bilirubin was estimated by diazo method of Pearlman and lee. Phototherapy was started for newborns with significant hyperbilirubinemia.

\section{Results}

Total 200 healthy term newborns were evaluated; male female ratio was 1.2. The mean gestation period was $39.24 \pm 1.12$ weeks. Maximum $(58 \% ; 116)$ women had full term normal vaginal delivery. The range of bilirubin on day one was $2.2-8.5 \mathrm{mg} / \mathrm{dl}$; majority newborns $(86.5 \%)$ did not develop significant hyperbilirubinemia.

\section{Discussion}

Early discharge of healthy term newborns from the hospital after delivery has recently become a common practice for medical, social and economic reasons. Hyperbilirubinemia is the most commonly reported cause for readmission during the early neonatal period. ${ }^{[1]}$ The current guidelines of the American Academy of Pediatrics recommend follow-up for newborns discharged before 48 hours of life at 2 to 3 days postnatally. ${ }^{[12]}$ However, a complete follow-up is not always possible because of the geography and climatic conditions, personal safety, or patient incompliance and the safety of relying on follow up visits after discharge is questionable as $10 \%$ of the population fails to return follow up visit.

Hence it is crucial to catalogue the babies who are at risk for significant jaundice before they are sent away from the hands of the pediatricians, and to prevent the potential bilirubin neurotoxicity so that, many of the significantly jaundiced neonates could see the light of the day from the nightmare of bilirubin encephalopathy.
The present study included term healthy newborns $>37$ weeks. The incidence of neonatal jaundice was inversely proportional to gestational age; no newborn with gestational age $>42$ weeks had total serum bilirubin $>4.9 \mathrm{mg} / \mathrm{dl}$. With increasing gestational age incidence of jaundice was decreased. This was due to maturity of hepatic clearance. Agarwal et al., ${ }^{[13]}$ reported similar findings.

The male female ratio significant hyperbilirubinemia developed babies was 1.07;

$52 \%(14 / 27)$ newborns who developed significant hyperbilirubinemia were male and $48 \%$ were female babies. Male gender is a known risk factor for hyperbilirubinemia. ${ }^{[14]}$ In a study by Naranget al., ${ }^{[15]}$ the incidence of hyperbilirubinemia in male was $64.2 \%$. Singhal et al., ${ }^{[16]}$ reported $56.8 \%$ and Alpay et al., ${ }^{[17]}$ reported $61.6 \%$ (37/60) hyperbilirubinemia among male babies. But incidence was found to be similar among gender by C.G vailaya et al. ${ }^{[18]}$

Out of 200 participants, 116newborns delivered by normal vaginal delivery; 76 by cesarean section and only 8 newborns required instrumentation either in the form of forceps or vacuum delivery. Oxytocin was mainly used to augment labor in $53 \%$ women. Out of 27 newborns who developed significant hyperbilirubinemia, oxytocin was used in mothers of $18(67 \%)$ newborn babies. Peak serum bilirubin levels were higher in neonates born after oxytocin induction of labor. Similar findings were reported by Singh et al., ${ }^{[19]}$ DP Davis et al. ${ }^{[20]}$

The first bilirubin level was done at 22-26 hours of birth. There is variability in the time of appearance of jaundice from newborn-newborn and in the ability of professionals to see jaundice and estimate its severity coupled with the considerable range of TSB associated with its cephalocaudal progression. Moreover the observer variability and the influence of the skin color in clinically evaluating hyperbilirubinemia.

In present study Hyerbilirubinemia was defined as TSB level $\geq 12 \mathrm{mg} / \mathrm{dl}$ between 24 to $48 \mathrm{hr}$ of life $\geq 15 \mathrm{mg} / \mathrm{dl}$ between 48 to $72 \mathrm{hr}$ of life and $17 \mathrm{mg} / \mathrm{dl}$ beyond 72 hours of life. ${ }^{[21]}$

In present study hyerbilirubinemia was defined if total serum bilurubin level was $\geq 12 \mathrm{mg} / \mathrm{dl}$ between 24 to $48 \mathrm{hr}$ of life and $\geq 15 \mathrm{mg} / \mathrm{dl}$ between 48 to $72 \mathrm{hr}$ of life and $17 \mathrm{mg} / \mathrm{dl}$ beyond 72 hours of life. ${ }^{[21]}$ As per Shivani et al., ${ }^{[22]}$ report, hyperbilirubinemia was defined as TSB level $\geq 12 \mathrm{mg} / \mathrm{dl}$ between 24 to $48 \mathrm{hr}$ of life $\geq 15 \mathrm{mg} /$ dlbetween 48 to $72 \mathrm{hr}$ of life and $17 \mathrm{mg} / \mathrm{dl}$ beyond 72 hours of life.

First bilirubin estimation was done at $24 \pm 6$ hours. Subsequent bilirubin estimation was done whenever clinical suspicion of jaundice exceeded $10.0 \mathrm{mg} \%$. Out of 200 newborns studied, 22 developed significant hyperbilirubinemia requiring phototherapy. TSB level of $6 \mathrm{mg} / \mathrm{dl}$ or less was present in 136 (63.8\%) newborns and only one developed hyperbilirubinemia. In the remaining 77 $(36.2 \%)$ neonates with TSB $>6 \mathrm{mg} / \mathrm{dl}$ subsequent 
hyperbilirubinemia developed in 21 (sensitivity 95\%, specificity $70.6 \%$ ). They concluded that Ideal cut off value was $5.0 \mathrm{mg} / \mathrm{dl}$ and babies with TSB levels higher than 6.0 $\mathrm{mg} \%$ had a significant risk of developing hyperbilirubinemia. In one similar prospective study by Alpay et al., ${ }^{[17]}$ concluded that use of $6 \mathrm{mg} / \mathrm{dl}$ as critical value at 24 hours of life predicted nearly all term neonates (sensitivity 90\%) with subsequent risk of significant hyperbilirubinemia $(>17 \mathrm{mg} / \mathrm{dl})$ \& will determine all those requiring phototherapy later on.

\section{Conclusion}

Early screening and appropriate management of hyperbilirubinemia is needed for prevention of complications in the newborn. This decreases the significant burden of untreated severe neonatal jaundice, causing potential neurological sequelae.

\section{References}

1. Stoll BJ, Kliegman RM. Jaundice and hyperbilirubinemia in the Newborn. In:Behrman RE, Kliegman RM, Jenson HB, Eds. Nelson Textbook of Pediatrics.19thedn. Philadelphia: WB Saunders Co; 2012; $603-604$.

2. M.J.Maisels, Kring E. Length of Stay, Jaundice and hospital readmission. Pediatrics. 1998; 101: 995 - 998.

3. Report 2002 - 03, National Neonatal Perinatal Database Network NewDelhi: National Neonatology Forum of India, 2006

4. Narayana S, Aggarwal, Upadhyay A, Deorari AK, Sindh M, Paul VK. Survival and morbidity in extremely low birth weight (ELBW) Infants. Indian Pediatrics, 2003; 40(2): 130 - 135.

5. Hall RT, Simson S, Smith MT. Readmission of breast fed infants in the first two weeks of life. J perinatal 2000; 20: $432-437$.

6. Lee K S, Perlman M, Ballantyne M. Association between duration of neonatal hospital stay and readmission rate. J Pediatr. 1995; 127: 758 766
7. Kiely M, Drum MA, Kessel W. Early discharge, risks, benefits and who decides. Clinperinatol. 1998; 25: 539 - 553.

8. Davidson LT, Merritt KK, Weech AA. Hyperbilirubinemia in the newborn. Am J Dis Child 1941; 61: 958 - 980.

9. Knudsen A. Prediction and non-invasive assessment of neonatal jaundice in the term healthy newborn infant. Acta Paediatr 1996; 85: 393 - 397.

10. Maisels MJ, Newman TB. Predicting hyperbilirubinemia in newborns: the importance of timing: Commentaries. Pediatrics 1999; 103(2): $493-$ 495.

11. Hall, R.T.,S.Simon, M.T.Smith. Readmission of breastfed infants in first 2weeks of life. J Perinatol. 2000; 20: 433 - 437.

12. American Academy of Pediatrics, Committee on Fetus and Newborn. Hospital stay for healthy term newborns. Pediatrics. 1995; 96: 788 - 790.

13. Agarwal R, Kaushal M, Paul VK, Deorah. Early neonatal hyperbilirubinemia using first day serum bilirubin level. Indian pediatrics 1997; 34: 429 - 432 .

14. Watchko JF, Oski FA. Bilirubin $20 \mathrm{mg} / \mathrm{dl}=$ Vigintiphobia. Pediatrics 1983; 71(4): $660-663$.

15. Narang A, Gathwala G, Kumar P. Neonatal Jaundice: An analysis of 551 cases. Indian Pediatr 1997; 34: 429 - 432.

16. Singhal PK, Singh M, Paul VK, Deorari AK, Ghorpade MG. Spectrum of neonatal hyperbilirubinemia: An analysis of 454 cases. Indian Pediatr 1992; 29: $319-325$.

17. Alpay F, Sarici U, Tosuncuk H, Serdar MA, Inanc N, Gokcay E. The value of first day bilirubin measurement in predicting the development of significant hyperbilirubinemia in healthy term neonates. Pediatrics 2000; 106: e 16.

18. C.G. Raghavendravailaya, Sheila Aiyer. Early Prediction of Significant Neonatal Hyperbilirubinemia using Serum Bilirubin Levels in Healthy term \& near term Newborns, Gujarath, India. J Pub Health Med Res 2014; 2(1): $14-19$.

19. Sunit Singh, Meharban Singh. Pathogenesis of oxytocin-induced neonatal hyperbilirubinaemia. J Neonat 2012; 12 (3): 332 - 338.

20. D P Davies, R Gomersall, R Robertson, P. Gray, A C Turnbull. Neonatal Jaundice and Maternal Oxytocin Infusion. British Med J 1973; 3: 476 477.

21. American Academy of Pediatrics, Practice parameters, Management of hyperbilirubinemia in the healthy term newborn Pediatrics 1994; 94(4): $558-567$.

22. Shivani Randev, Neelam Grover. Predicting Neonatal Hyperbilirubinemia using first day serum Bilirubin levels. Indian J Pediatrics 2010; 77 (2): 147 - 150 .

Copyright: (C) the author(s), 2019. It is an open-access article distributed under the terms of the Creative Commons Attribution License (CC BY 4.0), which permits authors to retain ownership of the copyright for their content, and allow anyone to download, reuse, reprint, modify, distribute and/or copy the content as long as the original authors and source are cited.

How to cite this article: Paramahamsa PRK, Sriram G, Koneru S, Chandra TJ. Diagnostic Utility of Measuring First Day Serum Bilirubin Levels in Management of Neonatal Hyperbilurubinemia. Asian J. Clin. Pediatr. Neonatol.2019;7(4):14-16.

DOI: dx.doi.org/10.21276/ajcpn.2019.7.4.3 